Analysis of the economic structure of the eating-out sector: the case of Spain

\title{
Laura Cabiedes-Miragaya
}

Department of Applied Economics, University of Oviedo, Spain

\section{Abstract}

The objective of this article is to analyse the structure of the Spanish eating-out sector from an economic point of view, and more specifically, from the supply perspective. This aspect has been studied less than the demand side, almost certainly due to the gaps which exist in available official statistics in Spain, and which have been filled basically with consumer surveys. For this reason, focus is also placed on the economic relevance of the sector and attention is drawn to the serious shortcomings regarding official statistics in this domain, in contrast to the priority that hotel industry statistics have traditionally received in Spain. Based on official statistics, a descriptive analysis was carried out, focused mainly, though not exclusively, on diverse structural aspects of the sector. Special emphasis was placed on issues such as business demography (for instance, number and types of enterprises, survival rates, size distribution, and age structure), market concentration and structure of costs. Among other conclusions, the analysis allowed us to conclude that: part of the sector is more concentrated than it may at first appear to be; the dual structure of the sector described by the literature in relation to other countries is also present in the Spanish case; and the impact of ICTs (Information and Communication Technologies) on the sector are, and will foreseeably continue to be, particularly 
relevant. The main conclusion of this study refers to the fact that consumers have gained prominence in their contribution to shaping the structure of the sector.

Key Words: eating-out sector

food service

restaurants

economic structure

ICT

Spain 


\section{Introduction}

The object of this article is to describe and analyse the structure of the eatingout sector in Spain from an economic perspective. Focus is also placed on the important economic contribution of the sector to the Spanish economy and, despite this, the serious shortcomings regarding official statistics in this domain.

In the field of food, increasing variety of ingredients and meals is a major trend of the twentieth century in affluent societies (Warde \& Martens, 2000). Spain is not an exception. Parallel to the vigorous economic growth that took place from the 1960s onwards, the diet of the Spanish population became increasingly diversified. A diet originally limited to cereals, pulses, tubers and little else, started to include fruits, vegetables and meat (Colino \& Martínez, 2015). At the same time, eating out ceased to be something exceptional and, with the introduction of innovative forms of delivery and elaboration, the variety in terms of cuisine and styles increased. One of the results of this process is that many Spanish restaurants and chefs nowadays enjoy high international prestige.

There exists very little research into the eating-out sector from the standpoint of supply. The eating-out phenomenon has been dealt with more from the perspective of demand. At least this is the case in the field of academic research in Spain (see, for instance, Díaz-Méndez \& García-Espejo, 2013; Díaz-Méndez \& García-Espejo, 2014; Díaz-Méndez et al. 2005), where, since 2000, a research group has been focusing attention on the Sociology of Eating (www.unioviedo.es/socialimen/).

The economic dimension of the sector in Spain (including restaurants, cafeterias, bars, and institutional catering) is far from negligible. Production 
reached almost 106 billion euros in 2014, that is, more than $5 \%$ of total production in the Spanish economy as a whole (Figuerola et al., 2015), and more than 111.5 billion euros in 2015 [calculation based on data of the FEHR (Federación Española de Hostelería; Spanish Hospitality Federation), 2016]. In contrast to what was generally perceived to be the case, the first figures provided on the sector, some 30 years ago, showed that restaurants exceeded hotels in turnover and employment level (García \& Pin, 2010; Guerra, 2009). Indeed, currently, around $85 \%$ of the main activity of the hospitality sector is represented by food and beverage service activities (FBSAs) provided at the above-mentioned establishments. Spain accounts for a $12.7 \%$ share of the EU27 total value added of the FBSA sector, the fifth highest share [after France (19.4\%), the United Kingdom (18.1\%), Germany (14.2\%) and Italy (13.1\%)], and is one of the most relatively specialised EU Member States in this economic subsector (see http://ec.europa.eu/eurostat/statistics-explained/).

Moreover, at the beginning of 2016 , there were more than $1,100,000$ people working in the sector [please see the INE (National Statistics Institute; Spanish Statistical Office) website at www.ine.es and Ministerio de Empleo y Seguridad Social (Ministry of Employment and Social Security) at www.empleo.gob.es/index.htm]. This amounts to $6.4 \%$ of the workers in the Spanish economy, with an unusually high percentage of self-employed as opposed to salaried workers, these self-employed workers representing $9.8 \%$ of the total (Turespaña, 2016). It must be pointed out that this high percentage of self-employed workers provides the sector with a certain stability in the face of fluctuations in the market (Figuerola et al., 2014). According to forecasts made by PricewaterhouseCoopers in relation to the creation of employment in Spain 
between 2013 and 2033, the FBSA sector is identified as the one which will experience the highest employment increase in the mentioned period, estimated at $70 \%$ (PwC, 2013). Leadership of the sector in this domain has similarly been confirmed in other reports (see, for example, Adecco, 2016).

There exist important barriers to accessing statistical data regarding the eatingout sector in Spain and, when statistics are available, they are usually subject to certain limitations, such as excessive grouping together of data. There exists no specific database and consequently statistical data sources are diffuse. Basically, the official data are elaborated and/or provided by the INE and the MAGRAMA (Ministerio de Agricultura, Alimentación y Medio Ambiente; Ministry of Agriculture, Food and Environment); the former being more oriented towards studying the supply side, and the MAGRAMA towards the demand side. All in all, the economic importance of the sector is undeniable from many perspectives, in particular regarding the tourist sector, which represented 10.9\% of the Spanish GDP in 2014 (please, see www.ine.es/jaxi/Datos.htm?path=/t35/p011/base 2010/serie/l0/\&file=01001.px), when Spain received 65 million non-resident tourists. This figure increased further to over 68 million in 2015.

It is not easy to estimate the relevance of FBSAs on tourism as a whole: for instance, the activity of cafeterias integrated in hotels is generally added to data regarding accommodation, and many surveys either ignore non-resident tourism or do not distinguish between tourists and non-tourists. It is estimated that non-resident visitors in Spain spend around $14 \%$ of their total budget in restaurants (Instituto de Turismo de España, 2012). This figure is underestimated, firstly because it refers exclusively to restaurants and also 
because of the increase in the importance of tourism packages in recent years. According to present figures (May 2016), around 23\% of the expenditure of nonresident visitors to Spain is currently channelled through packages (see www.ine.es/daco/daco42/egatur/egatur0516.pdf), hiding the amounts allocated specifically to meals eaten in restaurants. In turn, the tourist-related part of the production of the FBSAs had reached around $27-29 \%$ (of which 13 percentage points corresponded exclusively to non-resident tourism) in recent years, according to data from the INE (see www.ine.es/dynt3/inebase/index.htm?type=pcaxis \&path=/t35/p011/2009/\&file=p caxis). One of the aspects with which non-resident tourists are most satisfied when they visit Spain is gastronomy, obtaining, 8.3 points out of 10 compared to 7.7 points on average in 2009 (the highest score, together with that for accommodation) (Instituto de Estudios Turísticos, 2010).

The upward trend of the sector in Spain is linked not only to the importance of tourism, but also to socioeconomic changes and new social behaviours that have appeared since the 1960s. According to data from the MAGRAMA, eatingout expenditure represents one third of total food expenditure, or a higher proportion if national accounts data are used.

Some of the basic features of the Spanish eating-out sector that have been most frequently mentioned in the literature are its heterogeneous and dynamic nature, its seasonal character, its low level of human capital, the small size of its enterprises and the importance of the submerged economy (Bardón et al., 2007; Figuerola et al., 2015; García \& Pin, 2010; Guerra, 2009; Martín, 2003; Martín, 2004; Martín, 2009). 
The importance of the FBSAs is underlined by the fact that, since the 1960 s, the sector has been growing faster than the Spanish economy as a whole (Guerra, 2009). Nevertheless, the impact of the economic crisis has been particularly notable in Spain, as compared to other neighbouring countries such as France, Germany, Italy and the United Kingdom (according to data of NPD-CREST and the K-Index in MAGRAMA, 2012).

In order to put the evolution of the sector before and after the economic crisis into context, reference can be made to González \& Urtasun (2015), from the Bank of Spain Studies Service, where the evolution of consumption is analysed in real terms in two periods, 1996-2007 and 2008-2013, according to product type. The authors confirm that perishable non-essential goods have a greater elasticity of intertemporal substitution, growing by $3.6 \%$ in the period of boom and falling by $2.9 \%$ during the crisis. For restaurants and cafés, figures of $2.7 \%$ and $-3.1 \%$ respectively were obtained.

Finally, after successive falls in the eating-out spending of Spanish households during the period of the economic crisis, in 2015 the inter-annual variation begins to be slightly positive (1.2\%) (MAGRAMA, 2016, based on data of NPDCREST). The expenditure trend continues to be positive in 2016, due to the increase in the number of visits (above all, in quick-service restaurants) and, to a lesser extent, to an increase in the expenditure per customer. This trend could be interpreted as a reflection of the context of economic recovery, including a reduction in unemployment. (www.npdgroup.es/wps/portal/npd/es/noticias/ultimos-informes/). 
The remainder of this article proceeds as follows: section 2 refers to some conceptual and methodological issues; section 3 consists of a descriptive analysis of the economic structure of the sector, and the last section comprises the discussion and conclusions.

\section{Conceptual and other methodological issues}

The first difficulty when studying the eating-out sector from an economic perspective is to define the boundaries of the sector. If eating out, in the sense of meals eaten outside the home, is considered from a physical point of view, three modes of provision can be distinguished: commercial retail establishments, institutional catering and the communal mode, the first two belonging to the public sphere and the third to the private sphere (Warde \& Martens, 2000) (see Table 1). Given the non-commercial character of the communal mode of provision, it is not included in the eating-out sector when studied from an economic point of view, as is the case here. For that reason, the food outlets referred to in this article are commercial retail establishments and institutional catering. The terms eating-out sector and FBSA sector are used indistinctly.

Once differentiated conceptually, the statistical sources impose their own boundaries and limitations and the classification system used in each set of data becomes a determining factor in any study of the different outlets in the sector (please, see Table 2). 


\section{Table 1}

Eating out: Modes of provision

\begin{tabular}{|c|c|c|}
\hline \multicolumn{2}{|c|}{ The public sphere } & The private sphere \\
\hline \multicolumn{2}{|c|}{$\begin{array}{l}\text { Where: public settings. } \\
\text { Diverse denominations: eating-out sector, catering } \\
\text { industry, food service industry, out-of-home foodservice } \\
\text { market, food and beverage service activities (FBSAs), } \\
\text { HoReCa, }{ }^{\text {a }} \text { restaurant industry (in a in a narrower } \\
\text { sense)... }\end{array}$} & $\begin{array}{l}\text { Where: guests at someone } \\
\text { else's home. }\end{array}$ \\
\hline How it is organised: comm & odity exchange. & $\begin{array}{l}\text { How it is organised: } \\
\text { meals provided in a private } \\
\text { non-commercial setting } \\
\text { where visitors are present. }\end{array}$ \\
\hline $\begin{array}{l}\text { Commercial retail } \\
\text { establishments }\end{array}$ & Institutional catering & Communal meals \\
\hline $\begin{array}{l}\text { With ample boundaries, } \\
\text { automatic vending } \\
\text { machines, take-away } \\
\text { establishments, and even } \\
\text { some supermarkets (in } \\
\text { relation to meals fit for } \\
\text { immediate consumption) } \\
\text { may be included in the } \\
\text { sector. Nevertheless, in a } \\
\text { strict sense, if food is taken } \\
\text { back home to eat, these } \\
\text { cases should not be } \\
\text { considered modes of } \\
\text { eating out. }\end{array}$ & $\begin{array}{l}\text { Criteria of membership } \\
\text { rather than the ability to } \\
\text { pay (canteens or cafeterias } \\
\text { in factories, offices, } \\
\text { prisons, hospitals and } \\
\text { educational } \\
\text { establishments). In some } \\
\text { cases, it is possible to } \\
\text { speak of captive markets. } \\
\text { The service is contracted } \\
\text { by an institution and not by } \\
\text { the consumer. It may be } \\
\text { subsidized or free. }\end{array}$ & $\begin{array}{l}\text { Based on interpersonal } \\
\text { relationships and } \\
\text { reciprocity. }\end{array}$ \\
\hline
\end{tabular}

a International Union of National Organizations of Hotel, Restaurant and Café Proprietors, founded in 1949 (WIPO, 1973). HoReCa was translated later in broader terms, including hotels, restaurants and catering, instead of cafés. In 1997 this association merged with the International Hotels Association (IHA), becoming the current International Hotel \& Restaurant Association (IH\&RA) (please, see Guerra, 2009 and http://ih-ra.com/ihra-history/).

Source: Elaborated with the support of Warde \& Martens (2000). 
Table 2

Types of establishments providing food and beverage service activities, according to different statistical classification mechanisms

\begin{tabular}{|c|c|c|}
\hline $\begin{array}{c}\text { NACE }^{\mathrm{a}} \\
\text { (supply perspective) }\end{array}$ & $\begin{array}{c}\text { COICOPb } \\
\text { (demand perspective) }\end{array}$ & $\begin{array}{l}\text { NPD-CRESTc (demand } \\
\text { perspective) }\end{array}$ \\
\hline $\begin{array}{l}\text { Group } 56.1 \\
\text { - Restaurants } \\
\text { - Cafeterias } \\
\text { - Fast-food restaurants } \\
\text { - Take-out eating places } \\
\text { - Ice cream truck vendors } \\
\text { - Mobile food carts } \\
\text { - Food preparation in } \\
\text { market stalls } \\
\text { Group 56.2 } \\
\text { - Catering services } \\
\text { provided on public } \\
\text { transport, when carried } \\
\text { out by separate units } \\
\text { - Event catering, e.g.: } \\
\text { - for transportation } \\
\text { companies } \\
\text { - concessions at sports } \\
\text { and similar facilities } \\
\text { - canteens or cafeterias } \\
\text { (for factories, offices, } \\
\text { hospitals or schools) } \\
\text { - Group 56.3 } \\
\text { - Bars } \\
\text { - Taverns } \\
\text { - Cocktail lounges } \\
\text { - Discotheques } \\
\text { - Beer parlours } \\
\text { - } \text { Foffee shops juice bars } \\
\text { vendors }\end{array}$ & $\begin{array}{l}\text { Class } 11.1 .1 \\
\text { - Restaurants } \\
\text { - Cafés } \\
\text { - Buffets } \\
\text { - Bars } \\
\text { - Tearooms } \\
\text { - Kiosks } \\
\text { - Street vendors } \\
\text { - Automatic vending } \\
\text { machines } \\
\text { - Catering services } \\
\text { provided on public } \\
\text { transport, when priced } \\
\text { separately } \\
\text { - Catering contractor- } \\
\text { cooked dishes collected } \\
\text { by the customer or } \\
\text { delivered to the } \\
\text { customer's home } \\
\text { Class } 11.1 .2 \\
\text { - Canteens in } \\
\text { educational } \\
\text { establishments } \\
\text { - Works/office canteens } \\
\text { - Military messes and } \\
\text { wardrooms }\end{array}$ & $\begin{array}{l}\text { - Full service restaurants } \\
\text { - Quick service } \\
\text { restaurants, e.g.: } \\
\text { - self-service } \\
\text { - cafeterias } \\
\text { - taverns } \\
\text { - ice cream parlours } \\
\text { - food stores } \\
\text { - Immediate } \\
\text { consumption, } \\
\text { e.g.: } \\
\text { - take-away } \\
\text { - supermarkets } \\
\text { - kiosks } \\
\text { - bakeries } \\
\text { - convenience shops } \\
\text { - service stations } \\
\text { - Automatic vending } \\
\text { machines } \\
\text { - Work canteens (when } \\
\text { direct payment takes } \\
\text { place) } \\
\text { - Hotels (when direct } \\
\text { payment takes place) } \\
\text { - Catering services } \\
\text { provided on public } \\
\text { transport (when direct } \\
\text { payment takes place) } \\
\text { - Bars } \\
\text { - Discotheques } \\
\text { - Pubs }\end{array}$ \\
\hline
\end{tabular}

a NACE: The European statistical classification of economic activities, derived from ISIC, the United Nations' International Standard Industrial Classification of all economic activities. Facilities corresponding to division 56-NACE 2009 Rev.2: Food and beverage service activities. Automatic vending machines excluded. Group 56.1: Restaurants and mobile food service activities; Group 56.2: Event catering and other food service activities; and Group 56.3: Beverage serving activities. Source: Eurostat. (2008). 
${ }^{b}$ Classification of individual consumption by purpose, developed by the United Nations. Facilities corresponding to group 11.1: Catering services. Food and drink provided to hospital in-patients excluded. Class 11.1.1: Restaurants, cafés and the like and Class 11.1.2: Canteens. Source: United Nations Statistics Division. COICOP: detailed structure and explanatory notes. Available at: http://unstats.un.org/unsd/cr/registry/regcst.asp?Cl=5 (Accessed 10.05.2016).

${ }^{c}$ CREST: Consumer Reports on Eating Share Trends, sponsored by the NPD Group (a market research company). Source: MAGRAMA (Ministerio de Agricultura, Alimentación y Medio Ambiente; Ministry of Agriculture, Food and Environment), 2013 (Accessed 4.11.2016).

Official reports regarding eating out in Spain are frequently based on consumer surveys in which the exact establishments deemed to constitute "eating out" are not defined in advance, leaving it in the hands of those surveyed to define its boundaries. This is the case of some studies carried out within the framework of the Panel on Eating-Out Consumption (Panel del Consumo Alimentario Fuera del Hogar, see, e.g., MAGRAMA, 2011a and MAGRAMA, 2011b). On some occasions, the MAGRAMA uses the data which, since 2007, have been compiled by the market research company NPD, based on a sample of 120,000 individuals (see Table 2). More precisely, the data used is that contained in the Estudio sobre el mercado extradoméstico de alimentación / Study of the Eatingout Market (several years) and the data specifically referring to eating-out expenditure, contained in the Informe del consumo de alimentación en España I Report on Food Consumption in Spain (several years).

Any attempt to study the sector comes up against significant obstacles. One such obstacle is the fact that accommodation and FBSAs are often included in the same statistical item. This is quite a common drawback in the European Union (EU), aggravated by the most recent regulation; Regulation No 549/2013 of the European Parliament and of the Council of 21 May 2013 on the European 
system of national and regional accounts in the European Union. At least this is how, in Spain, the INE justifies the fact that publicly diffused data are divided into ever fewer items.

Prima facie, one relevant source when studying the sector is the EAS (Encuesta Anual de Servicios; Annual Survey on Services) carried out by the INE. However, it is not particularly reliable and is thus repeatedly criticised in the literature on the sector. For instance, sales figures are clearly underestimated when compared to the figures obtained in the national accounts, also elaborated by the INE. The submerged economy must certainly play some part in this incoherence.

To sum up, apart from excessive grouping and dispersion of the available public data, the fact that there exist inconsistencies between different data sources compiled by the same institution is a particularly serious problem. In the light of this, it is not surprising that official statistics in Spain associated to FBSAs do not provide enterprise micro-data, the kind of data which would make it possible to carry out econometric modelisations. In the absence of such data, a descriptive analysis was carried out, based on the structure-conductperformance (S-C-P) approach conceived by Edward S. Mason in the 1930s. This analysis is expounded in the following section and focuses mainly, though not exclusively, on certain structural aspects of the sector, that is, relatively stable features that make it possible to outline the context in which the enterprises carry out their business. The S-C-P approach is schematically represented in Fig.1, with the chain of causation running in both directions (feedback effects). 


\section{Figure 1}

\section{The structure-conduct-performance approach}

\section{Basic conditions}

\begin{tabular}{|l|l|}
\hline \multicolumn{1}{|c|}{ Supply } & Demand \\
- Technology & - Price elasticity \\
- Labour skills and organisation & - Substitutability \\
- Raw materials sources & - Cyclicality \\
- Value/weight & - Seasonality \\
- Transportation costs & - Rate of growth \\
- Location & - Purchase habits \\
- Legal framework & - Marketing features of the product and \\
& information searching \\
\hline
\end{tabular}
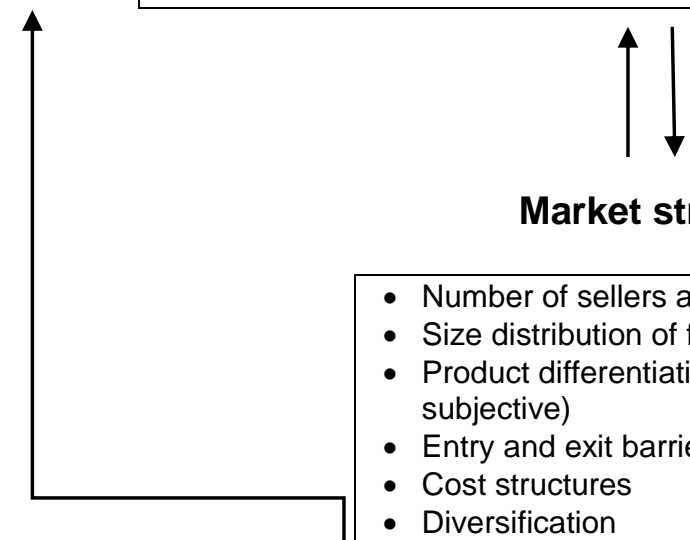

\section{Market structure}

- Number of sellers and buyers

- Size distribution of firms

- Product differentiation (physical or subjective)

- Entry and exit barriers

- Cost structures

- Diversification

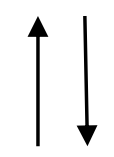

\section{Conduct}

- Pricing strategies

- Product design strategies

- Promotional strategies

- Advertising levels

- Research and development

- Plant investment

- Merger decisions

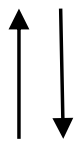

\section{Performance}

- Equity

- Technical efficiency (cost minimisation)

- Allocative efficiency

- Innovativeness (dynamic efficiency)

- Product quality

- Profits

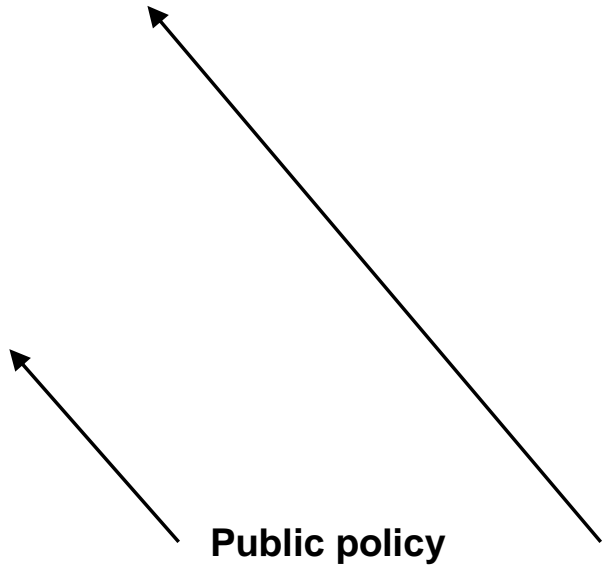

- Regulation

- Taxes and subsidies

- Incentives

- Public ownership

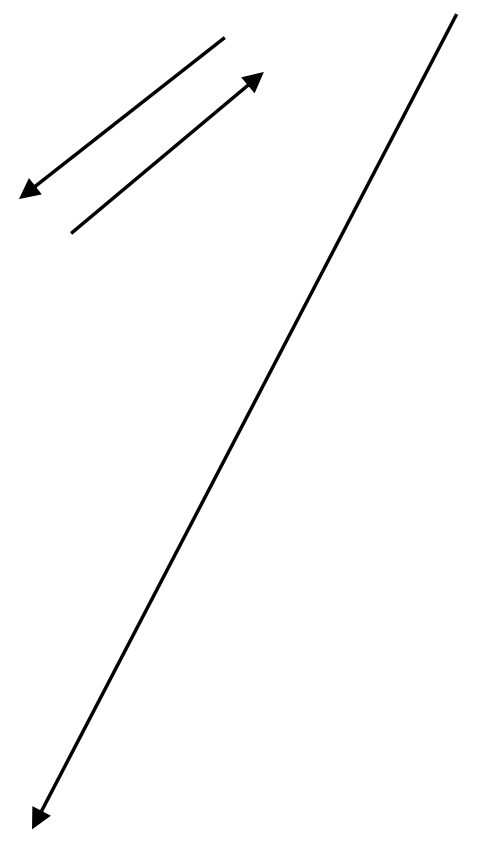

Sources: Porter (1981); Scherer (1980). 
Finally, just a few brief notes on the basic conditions relating to the eating-out sector. Although not always, in general, production and consumption activities coincide in time and space, above all in the case of restaurants, bars and similar establishments. In other words, food is generally produced when and where it is to be consumed by the client (Caves \& Murphy, 1976). With the exception of home deliveries, consumers must invest money and time in reaching the place where the service is provided (Martín, 2003), as is the case in the tourist sector in general (Bull, 1996). Consequently, a good location continues to offer an important competitive advantage. In this sense, location constitutes a key element to be taken into account when defining the market structure and conditions of competition of FBSAs in so far as the majority of these activities are in fact local services. In the FBSA sector, apart from location, product differentiation may be the result of the service provided and/or the quality of the raw materials used, as well as of the elaboration per se. In the case of franchising, given that differentiation does not exist among the enterprises that make up the group, the location of the establishments constitutes a key element of differentiation (Caves \& Murphy, 1976; Resa, 2005).

According to purchase habits, goods may be classified as follows: shopping goods, for which an evaluation process of alternatives takes place, given that price and quality comparison efforts are worthwhile (the gain relative to searching costs is sufficiently high); convenience goods, frequently bought with a minimum shopping effort (the above-mentioned ratio is low); and specialty goods, characterised by marked brand preferences, high prices and infrequent purchases (Holton, 1958; Kaish, 1967). Mobility has led to changes in the 
concept of convenience, enhancing opportunities for impulse shopping (Tauber, 1972). As regards convenience food in particular, Warde (1999) notes that "convenience is an issue not just of labour saving, but also of timing and space".

Likewise, goods may be classified depending on information that the consumers or users search for and obtain on them. The absence of perfect information on the services before buying them, together with the characteristics of the service itself makes it possible to distinguish between search, experience and credence goods (Nelson, 1970; Darby \& Karni, 1973). Objective and tangible attributes are associated to search goods, justifying previous searching and gathering of information. Experience goods, on the other hand, rich in sensory experiences such as taste, are mostly evaluated subjectively. In this case, personal experience prevails over other possible sources of information, such as friends' recommendations, advertising or rating services. Finally, credence goods are complex enough to require special expertise if they are to be evaluated correctly. Their results or performance may remain hidden even after they have been purchased (Lantos, 2011).

Given their nature, food and beverages are often classified as experience goods, with the exception of products of a complex nature, such as fine wine (Lantos, 2011).

\section{Descriptive analysis of the economic structure and other relevant} aspects of the sector

With regard to the economic policy applied to the sector in Spain in recent years, entrepreneurs have complained of certain regulatory measures with 
potentially negative effects on sales. These measures include the ban on smoking in closed public spaces, stricter opening times (currently, the closing time for restaurants and bars is $3.30 \mathrm{am}$ at the latest, as opposed to 6 am previously) and the successive increases in VAT rates, from 7\% in 2010 to $10 \%$ in 2012 in the case of the reduced rate of VAT applied to FBSAs in Spain as a result of the dependence of the Spanish economy on tourism and hospitality in general (Ernst \& Young, 2013). Unlike other countries, the sale of alcoholic drinks is extremely widespread in the majority of establishments of the sector in Spain and the only criterion applied to potential buyers of alcohol is their age (18 years of age). Furthermore, there have been no increases in the excise duties levied on alcoholic beverages in the last few years, wine being zero-rated in any case (Ernst \& Young, 2013).

\subsection{Number and types of enterprises and establishments}

The eating-out economic sector comprised 252,354 enterprises in 2015. More than two thirds of the total corresponded to beverage-serving activities and only 5 per cent to event catering and similar activities (see Fig. 2). 


\section{Figure 2}

Types of enterprises: Proportion of food and beverage service activities, 2015

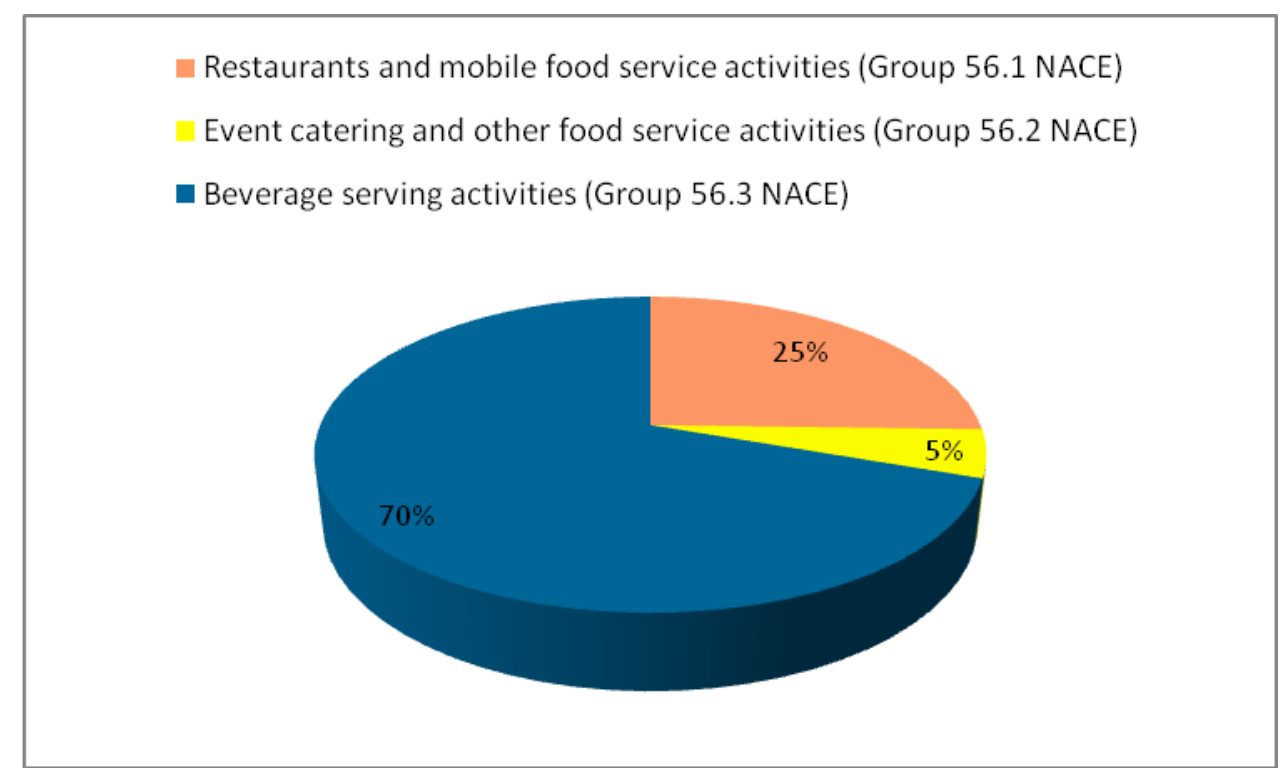

Source: Elaborated with data from DIRCE (Directorio Central de Empresas; Central Business Directory), INE (National Statistics Institute; Spanish Statistical Office). NACE 2009 Rev.2. Available at www.ine.es/jaxiT3/Tabla.htm?t=298\&L=0 (Accessed 23.06.2016).

Figure 3 shows the evolution of the number of enterprises and establishments in the sector, classified according to the main type of activities carried out (by groups), during the 2008-2015 period. It should be noted that increases or decreases in the number of enterprises must not be directly interpreted as a proxy of good or bad economic evolution. For instance, a decline may well reflect simply a strategy of entrepreneurial concentration. Nevertheless, grosso modo, such an interpretation is more plausible if the number of enterprises and establishments evolve in parallel, as is the case of restaurants, bars, and similar establishments. In view of the decline in the number of bars and other outlets 
included in the NACE (the European statistical classification of economic activities) group 56.3, both in terms of enterprises and establishments, it seems that the impact of the economic crisis has been quite severe for this type of establishments (see Fig. 3). According to data from the INE, between the "official starting date" of the economic crisis and 2015, the total number of businesses in Spain decreased by $6.9 \%$, falling to less than 3.2 million in the last year studied. The number of enterprises also decreased in the eating-out sector, albeit more moderately, by $5.3 \%$. This was due solely to the decrease in the number of bars, which fell by $8.4 \%$ between 2008 and 2015 . The number of enterprises associated with event catering (group 56.2 NACE), on the other hand, experienced a remarkable increase of $9.7 \%$, although this had little impact on the FBSA sector as a whole, given the minimal weight of this type of enterprise within the sector at the moment in Spain. In the same period, the increase in the number of establishments more than doubled the increase in the number of enterprises (19.8\% versus $9.7 \%$ ). This may well be indicative of a process of creation of chains and/or increased business concentration. How the gap between enterprises and establishments widened during the period studied can be seen in Fig. 3, albeit with difficulty given the scale that has had to be used. 


\section{Figure 3}

Number and types of enterprises and establishments: Food and beverage service activities, 2008-2015 (in thousands)

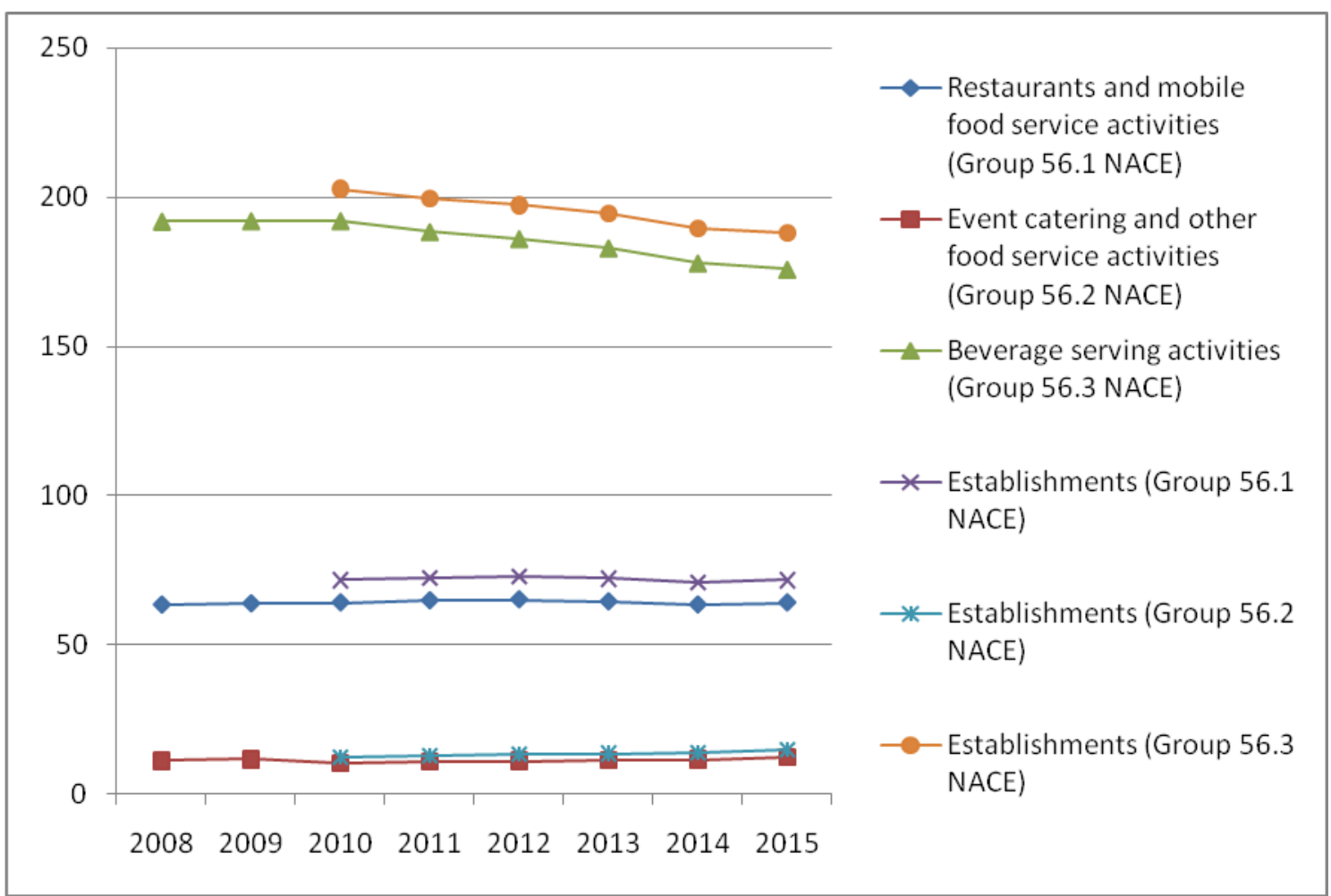

Source: Elaborated with data from DIRCE (Directorio Central de Empresas; Central Business Directory), INE (National Statistics Institute; Spanish Statistical Office). NACE 2009 Rev.2. Available at www.ine.es/jaxiT3/Tabla.htm?t $=298 \& \mathrm{~L}=0$ and www.ine.es/jaxiT3/Tabla.htm?t=294\&L=0 (Accessed 23.06.2016).

\subsection{Size distribution of businesses and market segments}

One possible way of measuring business size is through the number of employees. Table 3 shows this approach to the entrepreneurial structure. Two aggregate results are worthy of mention. Firstly, measured in this way, the enterprises in the eating-out sector are seen to be smaller than the average for the Spanish economy as a whole. Secondly, this is not, however, so for every group within the FBSA sector, given the higher proportion of large enterprises 
present in event catering and other food service activities in comparison with the overall average for the Spanish economy. Beverage-serving activities are represented principally by micro enterprises (employing fewer than 10 people).

\section{Table 3}

Size distribution of enterprises: Percentage of small and medium enterprises vs. large enterprises, 2008-2015

\begin{tabular}{|c|c|c|c|c|c|}
\hline & $\begin{array}{c}\text { The economy } \\
2008\end{array}$ & $\begin{array}{c}\text { Division } 56 \\
2008\end{array}$ & $\begin{array}{c}\text { Group } 56.1 \\
2008\end{array}$ & $\begin{array}{c}\text { Group } 56.2 \\
2008\end{array}$ & $\begin{array}{c}\text { Group } 56.3 \\
2008\end{array}$ \\
\hline SMEs (0-199) & 99.811 & 99.934 & 99.883 & 99.157 & 99.997 \\
\hline \multirow[t]{2}{*}{ LEs $(200$ or $>)$} & 0.189 & 0.066 & 0.117 & 0.843 & 0.003 \\
\hline & $\begin{array}{c}\text { The economy } \\
2009\end{array}$ & $\begin{array}{l}\text { Division } 56 \\
2009\end{array}$ & $\begin{array}{c}\text { Group } 56.1 \\
2009\end{array}$ & $\begin{array}{c}\text { Group } 56.2 \\
2009\end{array}$ & $\begin{array}{c}\text { Group } 56.3 \\
2009\end{array}$ \\
\hline SMEs (0-199) & 99.840 & 99.950 & 99.931 & 99.291 & 99.996 \\
\hline \multirow[t]{2}{*}{ LEs $(200$ or $>)$} & 0.160 & 0.050 & 0.069 & 0.709 & 0.004 \\
\hline & $\begin{array}{c}\text { The economy } \\
2010\end{array}$ & $\begin{array}{c}\text { Division } 56 \\
2010 \\
\end{array}$ & $\begin{array}{c}\text { Group } 56.1 \\
2010\end{array}$ & $\begin{array}{c}\text { Group } 56.2 \\
2010 \\
\end{array}$ & $\begin{array}{c}\text { Group } 56.3 \\
2010 \\
\end{array}$ \\
\hline SMEs (0-199) & 99.846 & 99.947 & 99.928 & 99.121 & 99.998 \\
\hline \multirow[t]{2}{*}{ LEs $(200$ or $>$ ) } & 0.154 & 0.053 & 0.072 & 0.879 & 0.002 \\
\hline & $\begin{array}{c}\text { The economy } \\
2011\end{array}$ & $\begin{array}{c}\text { Division } 56 \\
2011\end{array}$ & $\begin{array}{c}\text { Group } 56.1 \\
2011\end{array}$ & $\begin{array}{c}\text { Group } 56.2 \\
2011\end{array}$ & $\begin{array}{c}\text { Group } 56.3 \\
2011\end{array}$ \\
\hline SMEs (0-199) & 99.846 & 99.947 & 99.937 & 99.133 & 99.997 \\
\hline \multirow[t]{2}{*}{ LEs $(200$ or $>)$} & 0.154 & 0.053 & 0.063 & 0.867 & 0.003 \\
\hline & $\begin{array}{c}\text { The economy } \\
2012\end{array}$ & $\begin{array}{c}\text { Division } 56 \\
2012 \\
\end{array}$ & $\begin{array}{c}\text { Group } 56.1 \\
2012\end{array}$ & $\begin{array}{c}\text { Group } 56.2 \\
2012\end{array}$ & $\begin{array}{c}\text { Group } 56.3 \\
2012\end{array}$ \\
\hline SMEs (0-199) & 99.846 & 99.947 & 99.933 & 99.155 & 99.999 \\
\hline \multirow[t]{2}{*}{ LEs $(200$ or $>$ ) } & 0.154 & 0.053 & 0.067 & 0.845 & 0.001 \\
\hline & $\begin{array}{c}\text { The economy } \\
2013\end{array}$ & $\begin{array}{c}\text { Division } 56 \\
2013\end{array}$ & $\begin{array}{c}\text { Group } 56.1 \\
2013\end{array}$ & $\begin{array}{c}\text { Group } 56.2 \\
2013\end{array}$ & $\begin{array}{c}\text { Group } 56.3 \\
2013\end{array}$ \\
\hline SMEs (0-199) & 99.839 & 99.941 & 99.929 & 99.095 & 99.997 \\
\hline \multirow[t]{2}{*}{ LEs $(200$ or $>$ ) } & 0.161 & 0.059 & 0.071 & 0.905 & 0.003 \\
\hline & $\begin{array}{c}\text { The economy } \\
2014\end{array}$ & $\begin{array}{c}\text { Division } 56 \\
2014\end{array}$ & $\begin{array}{c}\text { Group } 56.1 \\
2014\end{array}$ & $\begin{array}{c}\text { Group } 56.2 \\
2014\end{array}$ & $\begin{array}{c}\text { Group } 56.3 \\
2014\end{array}$ \\
\hline SMEs (0-199) & 99.839 & 99.942 & 99.929 & 99.167 & 99.997 \\
\hline \multirow[t]{2}{*}{ LEs $(200$ or $>$ ) } & 0.161 & 0.058 & 0.071 & 0.833 & 0.003 \\
\hline & $\begin{array}{l}\text { The economy } \\
2015\end{array}$ & $\begin{array}{c}\text { Division } 56 \\
2015\end{array}$ & $\begin{array}{c}\text { Group } 56.1 \\
2015\end{array}$ & $\begin{array}{c}\text { Group } 56.2 \\
2015\end{array}$ & $\begin{array}{c}\text { Group } 56.3 \\
2015\end{array}$ \\
\hline SMEs (0-199) & 99.841 & 99.939 & 99.935 & 99.126 & 99.998 \\
\hline LEs $(200$ or $>)$ & 0.159 & 0.061 & 0.065 & 0.874 & 0.002 \\
\hline
\end{tabular}

Note: The economy: The Spanish economy as a whole. Division 56: division 56-NACE 2009 Rev.2: Food and beverage service activities. Group 56.1: Restaurants and mobile food service activities; Group 56.2: Event catering and other food service activities; and Group 56.3: Beverage-serving activities (see Table 2). SMEs: Small and medium-sized enterprises (0 to 199 persons employed). LEs: Large enterprises (200 or more persons employed).

Source: Elaborated with data from DIRCE (Directorio Central de Empresas; Central Business Directory), INE (National Statistics Institute; Spanish Statistical Office). Available at www.ine.es/jaxiT3/Tabla.htm?t=298\&L=0 (Accessed 6.06.2016). 
In close relation to the size of the enterprises, two different market segments have been differentiated within the sector: the independent segment and the organised segment. The first comprises small and medium-sized enterprises, often family-run, while the organised food service segment refers to chains of outlets with shared management and usually franchised. Even though this latter subsector has been gaining ground in Spain in recent decades, the independent segment represents a much higher share of the market (78-80\%) (Fernández, 2009; Fuentes, 2009; Guerra, 2009). This subsector is, however, generally considered to be oversized, at least as far as bars are concerned (Guerra, 2009).

The large size of the companies which it comprises and the exploitation of economies of scale are features of the organised segment, features which are particularly common among the enterprises classified as event catering and other food service activities (group 56.2 NACE), since they tend to be organized in chains. These conditions, together with competitive prices, have possibly facilitated the positive economic results obtained by the organised subsector, despite the economic crisis, currently approaching $20 \%$ of the Spanish market share. Within the franchising subsector, fast food franchises constitute the most important group, both in terms of turnover and employment, as well as being the one that has grown most during the economic crisis period (Tormo Franquicias Consulting, 2015).

In Spain, as in other countries which share a similar socio-economic environment, the franchise model has a significant presence in the eating-out sector (Sequeira et al., 2003). Currently, more than 1,100 chains operate in the Spanish economy (Tormo Franquicias Consulting, 2016a). Nevertheless, it 
developed much later than models found in economies such as that of the United States, for example. Indeed, in 1970, only 20 franchise chains were operating in the Spanish economy (Cuesta, 2004).

In 2015, 184 chains related to FBSAs were operating in the franchising subsector (one sixth of the total number of chains in Spain), with 7,010 establishments, a turnover of more than 3,800 million euros $(25 \%$ of the total turnover) and more than 72,000 employees (21\% of the employment). More than half of the turnover and over $43 \%$ of the employment corresponded to fast food franchises. In terms of importance, these were followed by "Bars specializing in beer and/or tapas" (Tormo Franquicias Consulting, 2016a). Although at the end of the 1980s the presence of Spanish and overseas chains was very similar, nowadays Spanish chains clearly outnumber overseas franchises, accounting for more than $80 \%$ of the total (Bordonaba et al., 2009; Martín, 2004). In Spain, as in Italy, local chains represent the dominant force (Figee \& Oortwijn, 2004), a prime example being that of Telepizza, founded in 1987, with almost 600 establishments operating in Spain (www.franquiciashoy.es/sector-franquicias-de-hosteleria-y-restauracion/10).

In the FBSA sector, the franchise model expanded considerably in the 1980s and, although with certain fluctuations, in general has continued to expand ever since (Bordonaba et al., 2009). Even in the years of the economic crisis, from 2008 to 2015 , the franchise system enjoyed much greater growth than the rest of the productive sectors of the Spanish economy (Tormo Franquicias Consulting, 2016b). The most noteworthy recent formulae, adapted to the Spanish market, include, for example, opening businesses in segments 
requiring low investment, such as chains of yogurt/ice-cream parlours and tapas establishments (Tormo Franquicias Consulting, 2014).

FBSAs generate a great deal of both employment in general and selfemployment, with franchises being particularly relevant with regard to the creation of self-employment. This is of tremendous importance in an economy like the Spanish one, with its meagre capacity to create jobs and high levels of unemployment.

After a downturn period (2009-2014), a slight growth in sales took place in 2015 in comparison to 2014 in the eating-out sector as a whole in Spain. Sales were concentrated in restaurants $(80 \%)$, followed by institutional catering $(4.1 \%)$, bars and discotheques (3.8\%), vending machines (2.9\%), hotels $(2.8 \%)$ and catering on public transport (less than 1\%) (MAGRAMA, 2016, with data from NPD-CREST).

Finally, new ways of providing food and beverage services in Spain, some of them innovative, are listed in Table 4. Among others, three possible factors explain these new formulae: the economic crisis (leading to greater price competition as well as greater utilisation of working spaces and industrial estates for lunch), more attention to health issues and socio-cultural changes.

\subsection{Business survival rates}

Business survival rates are presented in Table 5. With the available data, it has been possible to follow five birth cohorts. Survival in the eating-out sector is, throughout the period studied, lower than survival in the Spanish economy as a 
whole. In general, business survival decreased in parallel with the economic crisis, and, in the case of the eating-out sector, this was so for every year of the period studied. This all goes to show that this sector is particularly vulnerable to the economic context and, in particular, to the economic cycle.

\title{
Table 4
}

New ways of providing food and beverage services in Spain

\begin{abstract}
Formulae for expanding the traditional role (retailing): for instance, municipal food markets (sales-consumption mix in the same establishment, especially simple dishes and "tapas"), and bakeries.
\end{abstract}

Entry of non-food retail firms into the food service sector/mix of channels in the same space, as in the case of IKEA.

Integration of cafeterias and restaurants into malls.

Implants: integration of outlets within the working spaces; Grupo Viena Capellanes.

Chains of handmade yogurt and frozen yogurt, some with 100\% Spanish capital (for example, llaollao, franchise created in 2009, present in 28 countries), in line with increased sensitivity to health issues.

Online orders of home delivery food: Just.Eat, since 2011 in Spain, with more than 1,000 associated restaurants and 18,000 orders per month in 2012 (the network currently exceeds 4,000 restaurants). The internet has facilitated diversification and allowed restaurants from the independent segment to access the home delivery model (very centred in the beginning on fast food and pizzeria chains), allowing a wider range of choice.

Gastronomic tourism, for instance around the wine culture.

Low cost outlets

More contracting-out in the institutional sector

Restaurants for vegan clients

New forms of food provision on the street: food trucks

Source: Own elaboration. 


\section{Table 5}

Business survival rates: Food and beverage service activities (Division $56)^{a}$ vs. the economy as a whole (Percentage of enterprises surviving the given number of years) ${ }^{b}$

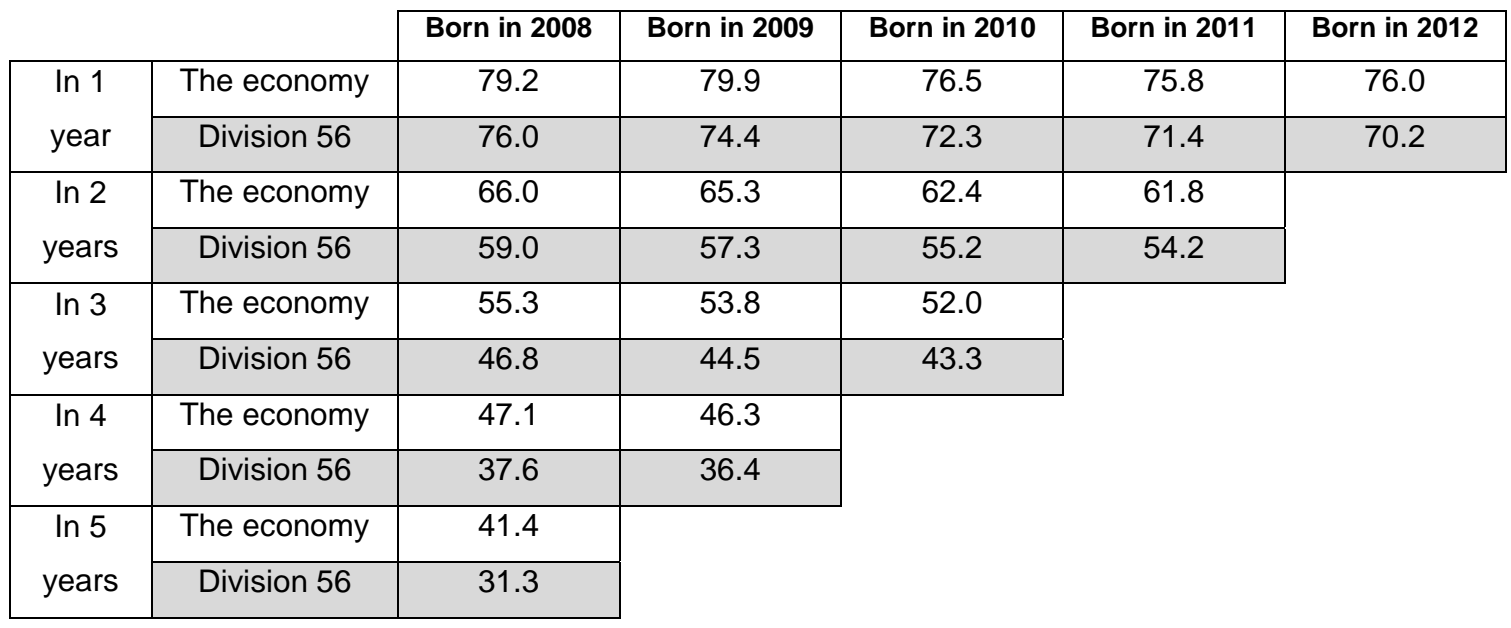

a Division 56-NACE 2009 Rev.2: Food and beverage service activities.

b The first and last data available in DAE is 2008 and 2013 respectively. Hence the period studied.

Source: Elaborated with data from DAE (Demografía Armonizada de Empresas; Harmonized Business Demography), INE (National Statistics Institute; Spanish Statistical Office). Available at www.ine.es/jaxi/menu.do?type $=$ pcaxis\&path $=\% 2 F t 37 \% 2 F p 204 \&$ file $=$ inebase\&L $\equiv 0$ (Accessed 6.06.2016).

\subsection{Age structure}

Business age structure is shown in Table 6 . The companies in the eating-out sector are younger than the average for the Spanish economy. Thus, while, in the economy as a whole, enterprises under four years old represent little more than $32 \%$ of the total, the proportion in the FBSA sector is 10 percent higher. Similarly, whilst almost $35 \%$ of the businesses in the economy as a whole are 12 or more years old, this applies to only $28 \%$ in the FBSA sector. These results give an insight into the dynamics of the sector and are coherent with the business survival rates obtained in both domains, briefly described previously. 
Another possible interpretation of these data would point to the relatively low entry barriers that characterise the eating-out sector in general.

\section{Table 6}

Age of enterprises: Food and beverage service activities (Division 56) versus the economy as a whole ( $1^{\text {st }}$ January 2015)

\begin{tabular}{|l|l|l|l|l|l|l|l|l|}
\cline { 2 - 8 } \multicolumn{1}{c|}{} & Total & $\begin{array}{l}\mathbf{0 - 1} \\
\text { years }\end{array}$ & $\begin{array}{l}\mathbf{2 - 3} \\
\text { years }\end{array}$ & $\begin{array}{l}\mathbf{4 - 7} \\
\text { years }\end{array}$ & $\begin{array}{l}\mathbf{8 - 1 1} \\
\text { years }\end{array}$ & $\begin{array}{l}\mathbf{1 2 - 1 5} \\
\text { years }\end{array}$ & $\begin{array}{l}\mathbf{1 6 - 1 9} \\
\text { years }\end{array}$ & $\begin{array}{l}\mathbf{2 0} \text { or } \\
\text { more } \\
\text { years }\end{array}$ \\
\hline $\begin{array}{l}\text { The } \\
\text { economy }\end{array}$ & $3,186,878$ & 627,366 & 404,097 & 558,874 & 483,976 & 356,760 & 278,852 & 476,953 \\
\hline $\begin{array}{l}\text { Proportion } \\
\text { (\%) the } \\
\text { economy }\end{array}$ & 100 & 19.69 & 12.68 & 17.54 & 15.19 & 11.19 & 8.75 & 14.97 \\
\hline $\begin{array}{l}\text { Division 56- } \\
\text { NACE }\end{array}$ & 252,354 & 66,771 & 39,682 & 43,938 & 30,610 & 24,172 & 18,346 & 28,835 \\
\hline $\begin{array}{l}\text { Proportion } \\
\text { (\%) } \\
\text { Division 56 }\end{array}$ & 100 & 26.46 & 15.72 & 17.41 & 12.13 & 9.58 & 7.27 & 11.43 \\
\hline
\end{tabular}

a Division 56-NACE 2009 Rev.2: Food and beverage service activities.

Source: Elaborated with data from DIRCE (Directorio Central de Empresas; Central Business Directory), INE (National Statistics Institute; Spanish Statistical Office). Available at www.ine.es/jaxi/menu.do?type $=$ pcaxis\&path $=\% 2 F t 37 \% 2 F p 201 \&$ file $=$ inebase \&L $\equiv 0$ (Accessed 6.06.2016).

\subsection{Market concentration}

Market concentration is an important aspect of the economic structure of a sector. The literature refers to the FBSAs as an atomized sector, with a low level of concentration and a structure categorised as monopolistic competition (Martín, 2009), the structure commonly associated with retailing. Monopolistic competition designates a structure with a high level of competition, that is, with many sellers and buyers and no substantial barriers to entry and exit, but 
differing from pure competition (based solely on price competition) due to differentiation of products.

Concentration ratios are often utilised to illustrate the low concentration of the eating-out sector as a whole: for example, how almost $60 \%$ of the market is composed of enterprises whose market share is less than 4\% (García \& Pin, 2010). Nevertheless, we should take into account the heterogeneity of the sector, in terms of the very different types of activities and establishments included within it, as well as the fact that the services involved are usually local ones. In this regard, in 2014, referring solely to restaurants, the share of the ten biggest enterprises $(\mathrm{C} 10)$ reached $9 \%$, but exceeded $51 \%$ when referring to event catering in general (including institutional catering) (DBK, 2016), this involving many more multinationals. Similarly, the validity of calculating different measures of concentration at a national level may be questioned if substitutability is analysed from the consumer perspective, since, in this case, the relevant market should be defined in terms of geographically smaller areas. Even so, it is enough to take a look at the array of restaurants, bars and similar activities in Spain to be able to assert that the possibilities of substitutability are indeed enormous. Obviously, this is only the case if cases of geographical monopolies (of ever decreasing importance due to better communications), and highly specialised services are excluded. The event catering-subsector (canteens included), with a far lower number of enterprises operating in the market, deserves a special mention. In this area, there is some evidence to suggest that the concentration measures utilised could be underestimating the actual concentration level and, in consequence, that some segments of the 
market should be categorised as oligopolies rather than monopolistic competition.

Though beyond the scope of this article, a tentative approach was attempted to be applied to catering events and similar activities (group 56.2 NACE) based on the private database SABI (Sistema de Análisis de Balances Ibéricos). In principle, the objective was to analyse concentration at province level or lower (depending on whether the population of the province exceeded or not one million inhabitants on $1^{\text {st }}$ January, 2015). However, it was found that, for a study of this kind, SABI has two shortcomings. The first of these is the fact that the number of companies included in this database is far smaller than the number of officially registered companies. The second drawback is the fact that this database allocates all the sales to the place where the company has its headquarters or is registered, and not to the individual locations where the sales were actually made. The first shortcoming is of minor importance, since when analysing concentration, the important thing is to take the largest companies into consideration, and this SABI does. The second shortcoming mentioned, however, cannot be ignored and for that reason further research is necessary in order to carry out a concentration analysis based on better defined relevant markets in the future.

\subsection{Structure of labour costs and training}

Table 7 shows some basic figures referring to the structure of labour costs both in the economy as a whole and in the accommodation and FBSA sectors in particular. In 2015, total labour costs per worker in the eating-out sector were 
somewhat in excess of 16,000 euros, around half of the cost for the economy as a whole (see Table 7). The labour costs in the accommodation sector were also below the average, but here the difference was far smaller. Among the diverse components of the labour costs, wages and salaries constitute the largest figure in all cases, representing almost $72 \%$ of labour costs in FBSAs, two percent below the average level for the economy as a whole. Resources dedicated to vocational training show relatively low levels in all spheres studied. However, the level is particularly low in the eating-out sector, hardly reaching $0.12 \%$ of total labour costs in 2015 , little more than a third of the average level in the Spanish economy. Even so, it should be noted that this proportion was 3 times greater in 2015 than seven years before (see Table 7).

\section{Table 7}

Labour cost structure per worker (annually): the economy as a whole and the accommodation and the eating-out sectors, 2008-2014

\begin{tabular}{|c|c|c|c|c|c|c|c|c|c|c|c|c|}
\hline & \multicolumn{3}{|c|}{ Absolute value, Divisions NACE in $€$} & \multicolumn{3}{|c|}{$\begin{array}{l}\text { Wages and salaries in } \\
\% \text {, Divisions NACE }\end{array}$} & \multicolumn{3}{|c|}{$\begin{array}{l}\text { Vocational training in } \\
\% \text {, Divisions NACE }\end{array}$} & \multicolumn{3}{|c|}{$\begin{array}{l}\text { Remainder of costs in } \\
\% \text {, Divisions NACE }\end{array}$} \\
\hline 2008 & $29,609.80$ & $24,147.80$ & $17,177.54$ & 73.1 & 72.6 & 72.3 & 0.35 & 0.15 & 0.04 & 26.6 & 27.2 & 27.7 \\
\hline 2010 & $30,819.53$ & $24,927.09$ & $16,818.21$ & 73.1 & 72.8 & 72.0 & 0.34 & 0.12 & 0.07 & 26.5 & 27.1 & 27.9 \\
\hline 2011 & $31,170.06$ & $25,451.92$ & $16,619.85$ & 73.1 & 73.1 & 71.5 & 0.36 & 0.12 & 0.09 & 26.6 & 26.8 & 28.4 \\
\hline 2012 & $30,905.55$ & $25,288.05$ & $16,069.14$ & 73.2 & 73.2 & 71.6 & 0.33 & 0.20 & 0.10 & 26.4 & 26.6 & 28.3 \\
\hline 2014 & $30,653.05$ & $26,391.17$ & $15,926.76$ & 73.8 & 72.9 & 71.8 & 0.33 & 0.17 & 0.10 & 25.9 & 27.0 & 28.1 \\
\hline 2015 & $30,857.31$ & $26,922.86$ & $16,120.07$ & 74.1 & 73.2 & 71.9 & 0.31 & 0.16 & 0.12 & 25.6 & 26.7 & 28.0 \\
\hline
\end{tabular}

\footnotetext{
${ }^{a}$ Econ: Sections $\mathrm{B}$ to $\mathrm{S}$, that is, the economy as a whole, excluding sections $\mathrm{A}$ (Agriculture, forestry and fishing); $\mathrm{T}$ (Activities of households as employers); and $\mathrm{S}$ (Activities of extraterritorial organisations and bodies)-NACE 2009 Rev.2.

${ }^{\mathrm{b}}$ Division 55-NACE 2009 Rev.2: Accommodation.

c Division 56-NACE 2009 Rev.2: Food and beverage service activities.

Source: Elaborated with data from INE (National Statistics Institute; Spanish Statistical Office), Encuesta Anual de Coste Laboral (Annual Labour Cost Survey). Data available at www.ine.es/jaxiT3/Tabla.htm?t=9126 (Accessed 8.11.2016).
} 
Even though there has been some criticism of the EAS in the literature for possibly underestimating certain figures (above all regarding sales), its use can to some extent be justified (see, for example, FEHR 2015). In our case, the labour costs data from the EAS were used because they are more broken down than the data used in Table 7 and given that no significant differences were found between the two sources for division 56 as a whole. The calculations carried out are shown in Table 8. Normality of the coefficient of variation (CV) was tested. The results obtained are significant at $1 \%$ to reject the null hypothesis of CV being higher than $10 \%$. This evidence confirms that the variability of remuneration per worker is very low between the three subsectors studied or, in other words, the mean of the three subsectors is representative. This result should come as no surprise, given the type of collective wage bargaining that exists in Spain. In this context, as pointed out by García \& Pin, 2010, the sector has very little margin for manoeuvre with regard to remuneration: "... it is what it is, in line with the wage agreements".

Given that absolute figures depend on working hours, one of the possible explanations for the low labour costs in the FBSA sector could be the relatively high weight of part-time employment. For this reason, if comparisons are to be made with other sectors, it is preferable to use labour costs and wage costs per effective hour worked. These data are presented in Fig. 4 and 5 respectively. This perspective permits us to assert that costs corresponding to FBSAs are well below those corresponding to both the economy as a whole and the accommodation sector. In concrete, in the first quarter of 2016, while the average labour cost per effective hour worked in Spain was 19 euros, in the 
eating-out sector it was 12 euros. With regard to wage costs, the figures were 14 and less than 9 euros, respectively.

\section{Table 8}

Labour costs per remunerated worker in the eating-out sector by NACE 2009 Rev. 2 Groups, annual mean in euros and coefficient of variation, 2008-2014

\begin{tabular}{|l|c|c|c|c|c|}
\cline { 2 - 6 } \multicolumn{1}{c|}{} & Group 56.1 & Group 56.2 & Group 56.3 & $\begin{array}{c}\text { Weighted } \\
\text { Mean }\end{array}$ & $\begin{array}{c}\text { Coefficient of } \\
\text { Variation }^{\mathbf{d}} \text { in \% }\end{array}$ \\
\hline 2008 & $18,351.12$ & $15,191.29$ & $16,593.37$ & $17,279.04$ & 6.74 \\
\hline 2009 & $18,620.63$ & $15,765.51$ & $16,549.16$ & $17,497.65$ & 6.72 \\
\hline 2010 & $19,183.16$ & $15,857.94$ & $16,334.57$ & $17,763.00$ & 8.48 \\
\hline 2011 & $19,009.03$ & $16,218.92$ & $16,424.32$ & $17,788.85$ & 7.44 \\
\hline 2012 & $19,338.83$ & $16,746.23$ & $16,097.20$ & $17,911.90$ & 8.52 \\
\hline 2013 & $18,891.35$ & $16,470.70$ & $15,292.28$ & $17,310.24$ & 9.61 \\
\hline 2014 & $18,789.25$ & $16,359.35$ & $15,133.46$ & $17,127.89$ & 9.86 \\
\hline
\end{tabular}

${ }^{a}$ Restaurants and mobile food service activities

b Event catering and other food service activities

${ }^{c}$ Beverage-serving activities

d The standard deviation divided by the mean

Source: Elaborated with data from EAS (INE). Available at www.ine.es/dyngs/INEbase/es/operacion.htm?c=Estadistica C\&cid=125473617

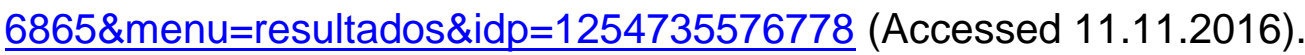

As in Europe in general, the FBSA sector is an important provider of "first jobs" that help the unemployed and migrants to (re)integrate into the labour market (Ernst \& Young, 2013). The sector suffers from a lack of both professionalization and prestige, high staff turnover and high degrees of job dissatisfaction. This situation is partly related to the small size of the enterprises, low wages and the almost total absence of human resource 
management. All of this constitutes a kind of vicious circle that will be difficult to break unless more training is made available to the sector (García \& Pin, 2010).

Figure 4

Labour cost per effective hour worked: the economy as a whole and the accommodation and the eating-out sectors, 2008-2016, by quarters.

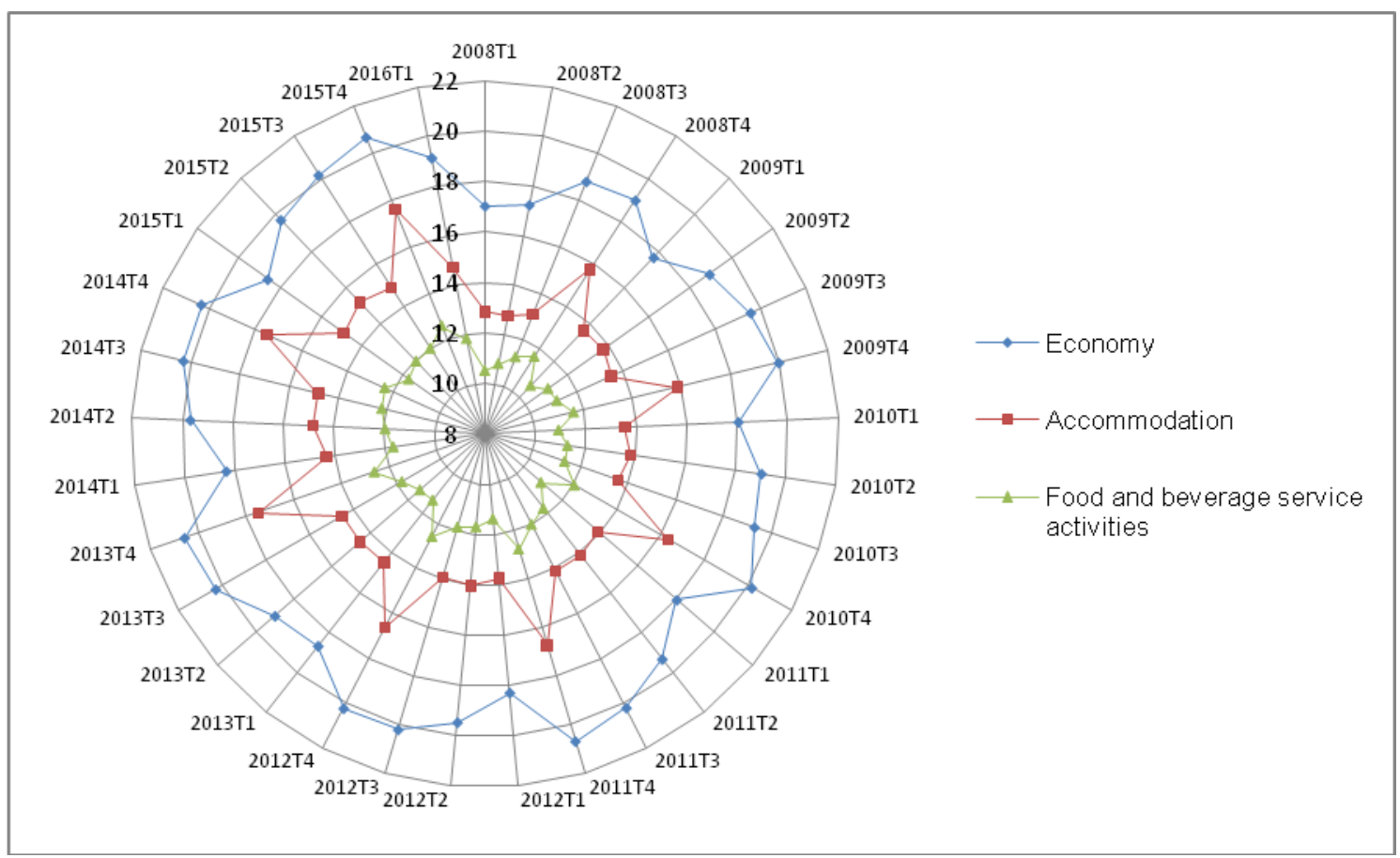

Note: Economy: Sections B to $\mathrm{S}$, that is, the economy as a whole, excluding sections A (Agriculture, forestry and fishing), $T$ (Activities of households as employers) and $S$ (Activities of extraterritorial organisations and bodies)-NACE 2009 Rev.2. Accommodation: Division 55-NACE 2009 Rev.2. Food and beverage service activities: Division 56-NACE 2009 Rev.2.

Source: Elaborated with data from INE (National Statistics Institute; Spanish Statistical Office). Data available at www.ine.es/jaxiT3/Tabla.htm?t=6037\&L=0 (Accessed 21.06.2016). 


\section{Figure 5}

Wage cost per effective hour worked: the economy as a whole and the accommodation and the eating-out sectors, 2008-2016, by quarters

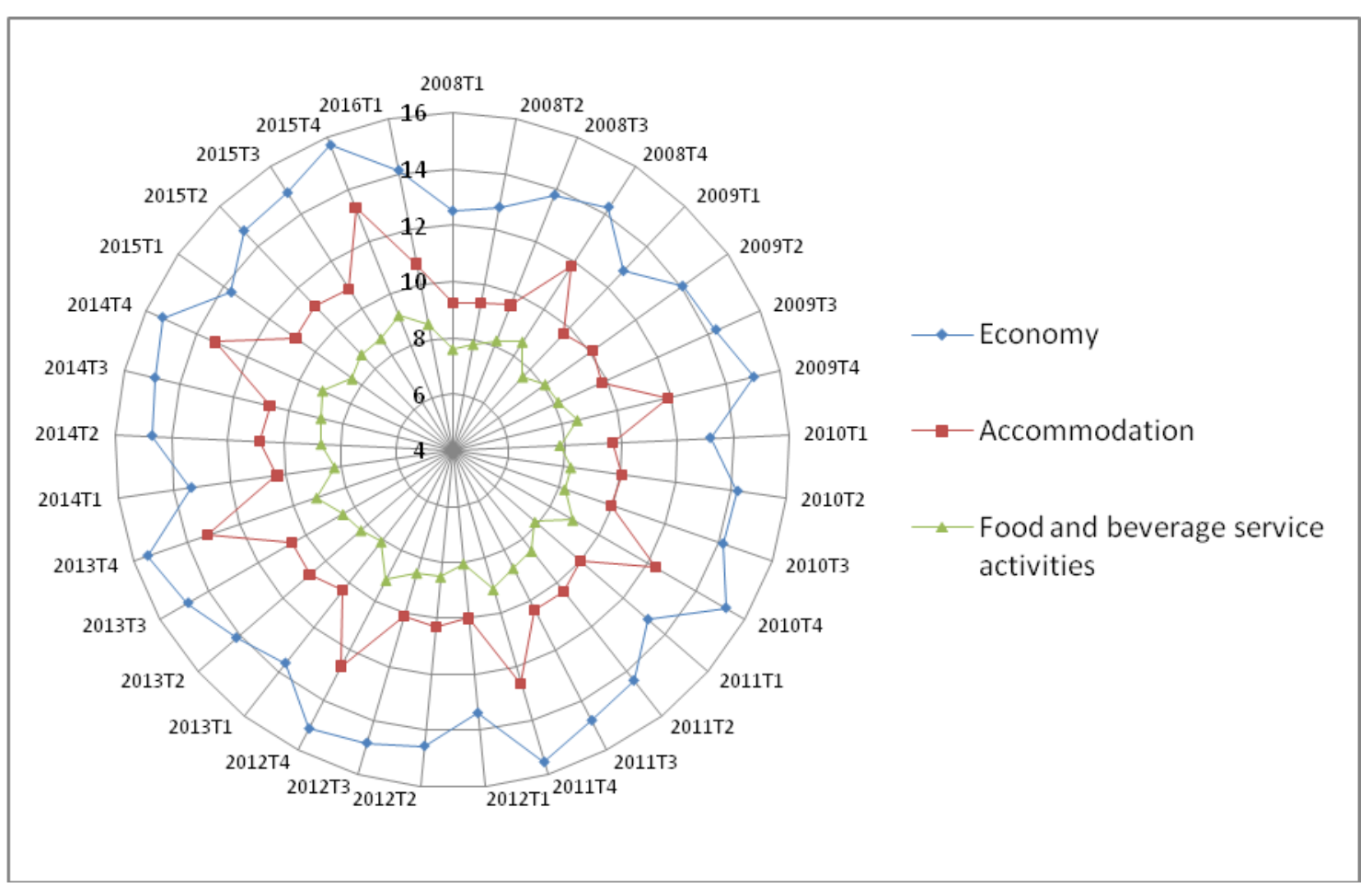

Note: Economy: Sections B to $\mathrm{S}$, that is, the economy as a whole, excluding sections A (Agriculture, forestry and fishing), $T$ (Activities of households as employers) and $S$ (Activities of extraterritorial organisations and bodies)-NACE 2009 Rev.2. Accommodation: Division 55-NACE 2009 Rev.2. Food and beverage service activities: Division 56-NACE 2009 Rev.2.

Source: Elaborated with data from INE (National Statistics Institute; Spanish Statistical Office). Data available at www.ine.es/jaxiT3/Tabla.htm?t=6037\&L=0 (Accessed 21.06.2016).

Training is practically non-existent in the majority of enterprises in the sector in Spain. Besides, the training plans offered do not correspond to the actual needs of the sector (García \& Pin, 2010). It is nevertheless true that the training plans offered in recent years in Spain have increased both in number and diversity, especially at university level. Among other subsequent initiatives, in 2009, the Basque Culinary Center, belonging to the Mondragon Corporation, created the 
"Facultad de Ciencias Gastronómicas" (School of Gastronomic Sciences), the first university centre to specialise in this area.

The conclusion is that more education is needed in the sector at all levels. In particular, more trained waiters are required and it is necessary to employ criteria other than mere "experience" in recruitment processes.

\subsection{The use of ICTs (Information and Communication Technologies)}

The increasing use of ICTs (Information and Communication Technologies) has revolutionised our lives, to such an extent that it is not clear what place they should occupy in Fig. 1. Nevertheless, whether associated to the conduct or to the performance domain, their potential impact on the structure of the sector is unquestionable. Platforms or consumer review websites make it possible to channel opinions exponentially. ICT applications constitute an efficient way of diffusion of promotional, advertising and discount strategies, as well as a powerful tool for managing reservations in real time.

Among the most widely used specialised platforms for online reservations in Spain the following are worthy of mention: www.eltenedor.es/ (with more than half a million opinions, affiliated to the French company La Fourchette, recently acquired by the TripAdvisor company); www.restaurantes.com; and www.verema.com/blog.

Online reservations have increased exponentially in Spain in recent years. For instance, in 2012, with 1.3 million reservations, the level doubled that attained the previous year. In 2013 there were 3.5 million reservations, which 
represented the mobilization of 38 million euros (http://tecnologia.elpais.com/tecnologia/2014/01/15/actualidad/1389788493 89 6284.html). Given the low starting levels, significant growth may be expected in the near future.

Decisions are increasingly influenced by consumer opinions expressed through social networks, these having become the second most important factor in decision-taking after the price-quality criterion (http://blog.thefork.com/es/reservasonline2014/). Consumer reviews are affecting restaurant revenue and it is independent restaurants that are increasing their market share to the detriment of restaurant chains (Luca, 2016). Despite this, only 3\% of restaurants in Spain have an online reservation system, due to the absence of a computer, of knowledge or of the adequate staff to deal with this kind of device (www.turispain.com/blog/reservas-online-restaurantes/). Nevertheless, for quite a long time now, the Internet has been used for consultation before making a reservation in Spain (MMAMRM, 2008). Similarly, in a survey carried out by FEHR of 10,000 business owners in the hospitality sector, $73 \%$ of them affirm that they publicize their businesses through their webpage and $20 \%$ say they are extremely active in social networks (FEHR, 2015). Indeed, the FEHR recently signed an agreement with Theysay.me with a view to helping restaurants to manage their online image (please see, http://blog.theysay.me/tag/fehr/ and the franchises are taking measures to reinforce their presence in social networks (www.quefranquicia.com/articulos/las-grandes-relaciones-de-twitter-con-lasfranquicias-de-restauracion 15324.html). 
Finally, although analysis of the use of ICTs in this sector in Spain is difficult due to the lack of statistical information currently available, it is important to mention the data provided in recent years by the Observatorio Nacional de las Telecomunicaciones y de la Sociedad de la Información (National Observatory for Telecommunications and the Society of Information; ONTSI, red.es). The item "restaurants" is mentioned for the first time in the 2012 edition of the Estudio sobre Comercio Electrónico B2C; Study of B2C Electronic Commerce (see, for example, Urueña et al., 2015; the last edition available). The information refers both to reservations and orders for home-delivery made by online purchasers (clarification kindly provided by A. Urueña, the coordinator of the publication). For the period 2011-2014, the absolute number of buyers increased by $83 \%$ (calculation based on data from www.ontsi.es). At the moment, one clear conclusion to be drawn from the data is the predominance of online purchases in cities of more than 100,000 inhabitants in comparison with all other locations. This fact is, in all likelihood, related to the greater presence of chains of restaurants and franchises in big cities (for more information regarding the requirements of some chains of franchises in terms of minimum population size, see Martín, 2004).

\section{Discussion and conclusions}

The contribution of the sector to the Spanish economy is unquestionable. In this sense, we conclude, as do other authors (García \& Pin, 2010), that it deserves more official attention, in particular in terms of available statistics. 
The phase of the economic cycle has had unequal effects on businesses in the sector. The decline in the number of bars in Spain in recent years seems to be related to the greater impact of the economic crisis on the smallest businesses, as is documented in the literature. In general, smaller enterprises and highly labour-intensive activities are related to highly competitive markets and lower survival rates. It is, therefore, not surprising that lower survival rates are identified in the service and trade industries, and, in particular, in enterprises related to accommodation and gastronomy (Kalleberg \& Leicht, 1991; Lobos \& Szewczyk, 2012). Furthermore, microenterprises (no employees) exhibit the lowest survival rates (Lobos \& Szewczyk, 2012). Unfortunately, there are no official enterprise micro-data related to the sector which might make it possible to analyse this matter in greater depth, but there is some evidence that low barriers to entry and low professionalism may have also contributed to the inadequate performance of smaller enterprises, and bars in particular, in Spain. In any case, inadequate adaptation to the industry environment in which bars compete and failure (often due to inefficiency) could be a good example of feedback effects in the S-C-P approach. In other words, not only does structure determine conduct and performance, but performance and conduct also determine certain structural elements of the sector.

The descriptive analysis carried out permitted us to detect a dual structure in terms of the size of the enterprises, as well as in relation to the degree of differentiation in the services provided.

The presence of numerous small and medium-sized enterprises coexisting with some large corporations had previously been detected in other countries such as, for example, the United Kingdom (Warde \& Martens, 2000). 
The two extreme patterns in terms of differentiation are in part a reflection of the above-mentioned dual structure: standardisation and mass production (with similarities to industrial production processes) versus sophisticated and tailored services with high levels of specialisation and technical (not only subjective) differentiation. As in the case of the United Kingdom (Warde \& Martens, 2000), many examples of standardisation and of specialisation can be identified in the Spanish eating-out sector.

Restaurant chains standardise processes, economize on staff, and obtain important economies of scale. At the opposite end of the scale, the service itself may constitute a key element, even to the extent of requiring more than one employee per client, as was the case in El Bulli (1962-2011), the restaurant that belonged to the innovative chef Ferrán Adrià. Although many "haute cuisine" restaurants suffer economic losses, they usually also exploit other lines of business, which can be extremely profitable. At a macroeconomic level, while their weight in the sector is negligible, their indirect effects (backward and forward effects) may be considerable in terms of culinary trends, image and prestige, and international marketing of autochthonous products and tourist services in general.

ICTs may influence the structure of the sector in different ways. In general terms, ICTs may or may not enhance competition forces, and hence the effect on market structure is in principle uncertain. On the one hand, social networks permit a global approach and the Internet facilitates efficient promotional and advertising strategies. Thus, the Internet could contribute to offsetting the influence of the larger firms in the sector, given that small enterprises can become well-known at a relatively low cost. This more global approach, 
extending to tourism, may enhance competitive forces and, in consequence, reduce or at least temper the dual character of the sector. Internet tools also make it possible to discriminate between different client profiles, that is, to segment the market. As a consequence, in this sense, the market structure may become more imperfect.

Social networks contribute to reducing the costs of searching for price and quality information and the Internet allows consumers to obtain information about the quality of food and beverage services without the need to purchase them. As a result, the majority of FBSAs could well nowadays be considered not so much experience goods as search goods. This possibility, more than a mere academic issue, may have important consequences on the structure of the sector, and ultimately on consumer welfare since search goods are more exposed to competition than either experience or credence goods, for which low prices could be taken as signs of low quality. Indeed, many sommeliers may take advantage of our lack of knowledge and manipulate our choices, foreseeing that customers will tend not to choose the cheapest wine on the wine list.

In a similar vein, Huang, Lurie \& Mitra (2009) carried out an interesting experiment applied to three products which have traditionally been classified as search goods (shoes, home furniture and garden implements) and three traditionally classified as experience goods (automobile parts and accessories, health and beauty products and camera equipment). We consider that their main conclusion can also be applied to the eating-out sector in Spain: "By lowering the costs of gathering and sharing information and offering new ways to learn about products before purchase, the Internet reduces traditional 
distinctions between search and experience goods" (Huang, Lurie \& Mitra, 2009).

With regard to the eating-out subsector specifically associated with highways, airports, and railroad stations, the lack of honesty that sometimes characterises this segment of the market could be reduced as a result of review platforms, as they may dissuade sporadic clients against using bad or excessively expensive services. Equally, however, the existence of review fraud on online platforms may act against fair competition despite the existence of several mechanisms aimed at reducing it (Luca \& Zervas, 2015).

Other potential effects of ICTs on the structure of the eating-out sector may act in an indirect way. For instance, online shopping is having an important impact on Spanish real estate. With fewer businesses requiring in-town premises, these are increasingly being occupied by establishments providing food and beverage services. This situation, together with the real estate bubble, has forced prices and rents down. In consequence, entry barriers have decreased, with more and cheaper options in terms of opening an establishment. At the same time, exit barriers may increase for the proprietors of the premises, given the sunk costs tied to them and the potential difficulties involved in transferring restaurant or bar premises to other activities.

There is some evidence to suggest that the sector is more concentrated than it may appear prima facie. Further research is necessary in this domain. In particular, one possible future line of research would be to focus on measuring concentration levels based on relevant markets which are better adjusted to the local character of the services included in the sector. 
Finally, the main conclusion of this study refers to the fact that consumers have gained prominence in their contribution to shaping the structure of the sector.

\section{Acknowledgements}

The author belongs to the research group in Sociology of Food of the University of Oviedo in Spain. The objective of the group is to analyse food changes in modern societies. This study has been prepared within the framework of the research projects financed by the Spanish National Research Plan (Ref. CSO2012-31904 and Ref. CSO2015-68434-R).

\section{References}

Adecco. (2016). Informe Adecco sobre el futuro del trabajo en España. Madrid: Adecco. Available at www.adecco.es/ data/NotasPrensa/pdf/737.pdf (Accessed 13.07.2016).

Bardón, R., Belmonte, S., Cano, M., Fúster, F., Gómez, J.V., Hernández, M. et al. (2007). Análisis descriptivo del canal HORECA en la Comunidad de Madrid. Situación actual y perspectivas. Coordinated by Vilas, F. Madrid: Consejería de Sanidad. Dirección General de Salud Pública y Alimentación. Documentos Técnicos de Salud Pública no 118.

Bordonaba, V., Lucía, L. \& Polo, Y. (2009). Evolución del sistema de franquicia en España: un estudio en los sectores de moda y hostelería. Distribución y Consumo, 105, May-Juin, 64-76.

Bull, A.O. (1996). Economía del sector turístico. Información Comercial Española, 749, January, 9-15.

Caves, R.E. \& Murphy, W.F. II (1976). Franchising: Firms, Markets, and Intangible Assets. Southern Economic Journal, 42 (4), 572-586.

Colino, J. \& Martínez, J. M. (2015). Sector agrario. In García Delgado, J. L. and Myro, R. (eds.), Lecciones de Economía Española (12ª edition). Pamplona: Thomson-Reuters, 145-162.

Cuesta, P. (2004). La franquicia: una fórmula comercial con éxito en pleno crecimiento. Distribución y Consumo, 78, November-December, 5-13.

Darby, M.R. \& Karni, E. (1973). Free Competition and the Optimal Amount of Fraud. Journal of Law and Economics, 16 (1), 67-88.

DBK. (2016). El Mercado de hostelería y colectividades. Informe especial. Madrid: DBK. 
Díaz-Méndez, C. \& and García-Espejo, I. (2013). La alimentación fuera del hogar. In Díaz-Méndez, C. (ed.), Hábitos alimentarios de los españoles. Madrid: Ministerio de Agricultura, Alimentación y Medio Ambiente (Ministry of Agriculture, Food and Environment), 47-61.

Díaz-Méndez, C. \& García-Espejo, I. (2014). Eating practice models in Spain and the United Kingdom: A comparative time-use analysis. International Journal of Comparative Sociology, 55 (1), 24-44.

Díaz-Mendez, C., Herrera, P., Callejo, J. \& Alonso, L. E. (2005). Análisis crítico de las fuentes estadísticas de consumo alimentario en España. Una perspectiva sociológica. REIS (Revista Española de Investigaciones Sociológicas), (110), 117-136.

Ernst \& Young. (2013). The Hospitality Sector in Europe. An assessment of the economic contribution of the hospitality sector across 31 countries. Report commissioned by The Brewers of Europe with support from Hotrec (Hospitality Europe).

European Parliament and the Council. (2013). Regulation (EU) No 549/2013 of the European Parliament and of the Council of 21 May 2013 on the European system of national and regional accounts in the European Union. Official Journal of the European Union, 26.06.2013, L 174/1-727. Available at http://eurlex.europa.eu/legal-content/EN/TXT/PDF/?uri=CELEX:32013R0549\&from=EN

Eurostat. (2008). NACE Rev. 2. Statistical classification of economic activities in the European Community. Eurostat Methodologies and Working Papers. Luxembourg: European Communities. Available at http://ec.europa.eu/eurostat/documents/3859598/5902521/KS-RA-07-015EN.PDF (Accessed 10.05.2016).

FEHR. (2015). El sector avanza en la digitalización de los negocios. Revista FEHR (Federación Española de Hostelería; Spanish Hospitality Federation), 32, 14-15. Available at www.hosteleriadigital.es/publicaciones (Accessed 14.11.2016).

FEHR. (2016). Los sectores de la hostelería en 2015. Revista FEHR (Federación Española de Hostelería; Spanish Hospitality Federation), 35, 1417. Available at www.hosteleriadigital.es/publicaciones (Accessed 14.11.2016).

Fernández, P. (2009). Claves del Canal Horeca organizado. Barcelona: AECOC (Asociación Española de Codificación Comercial).

Figee, E. \& Oortwijn, M. (2004). High Pressure Cooking. European foodservice market matures, while value chain dynamics just start. Utrecht: Cap Gemini Ernst \& Young.

Figuerola, M., Herranz, J.L., Rubio, J.M., Gallego, E., Navarro, J. \& Pérez, L. (2014). Los sectores de la hostelería en 2013. Madrid: FEHR (Federación Española de Hostelería; Spanish Hospitality Federation). 
Figuerola, M., Herranz, J.L., Rubio, J.M., Gallego, E., Navarro, J. \& Pérez, L. (2015). Los sectores de la hostelería en 2014. Madrid: FEHR (Federación Española de Hostelería; Spanish Hospitality Federation).

Fuentes, C. (2009). Un doble punto de vista en el sector de hostelería y restauración: el del empresario y el del consumidor. Distribución y Consumo, 103, January-February, 17-31.

García, P. \& Pin, J. R. (2010). La rotación en el sector de la restauración en España. Causas, consecuencias y líneas de actuación. IRCO (International Research Center on Organizations) and InsedNetwork (International Network for Service Enterprise and Education Development).

González, J. \& Urtasun, A. (2015). La dinámica del consumo en España por tipos de productos. Boletín Económico. Banco de España, September, 69-78.

Guerra, J. L. (2009). El sector de la restauración en España. Distribución y Consumo, 103, January-February, 32-39.

Holton, R.H. (1958). The Distinction between Convenience Goods, Shopping Goods, and Specialty Goods. Journal of Marketing, 23 (1), July, 53-56.

Huang, P., Lurie, N.H. \& Mitra, S. (2009). Searching for Experience on the Web: An Empirical Examination of Consumer Behavior for Search and Experience Goods. Journal of Marketing, 73, 55-69.

Instituto de Estudios Turísticos. (2010). Balance del Turismo. Año 2009. Madrid: Instituto de Estudios Turísticos, Ministerio de Industria, Energía y Turismo (Ministry of Industry, Energy and Tourism). Available at http://estadisticas.tourspain.es/es-

ES/estadisticas/analisisturistico/balantur/anuales/Balance\%20turismo\%20en\%2 0Espa\%C3\%B1a\%20en\%202009.pdf (Accessed 5.07.2016)

Instituto de Turismo de España. (2012). Informe anual 2012. Madrid: Instituto de Turismo de España, Ministerio de Industria, Energía y Turismo (Ministry of Industry, Energy and Tourism). Available at http://estadisticas.tourspain.es/eses/estadisticas/egatur/paginas/default.aspx (Accessed 5.07.2016).

Kaish, S. (1967). Cognitive Dissonance and the Classification of Consumer Goods. Journal of Marketing, 31, October, 28-31.

Kalleberg, A.L. \& Leicht, K.T. (1991). Gender and organizational performance: Determinants of small business survival and success. Academy of Management Journal, 34 (1), 136-161.

Lantos, G. P. (2011). Consumer Behavior in Action. Real-life Applications for Marketing Managers. London and New York: Routledge. 
Lobos, K. \& Szewczyk, M. (2012). Survival analysis: A case study of micro and small enterprises in Dolnoslaskie and Opolskie Voivodship (Poland). Ekonomická Revue, 15: 207-216.

Luca, M. (2016). Reviews, Reputation, and Revenue: The Case of Yelp.com. Harvard Business School. Working Paper 12-016. Available at www.hbs.edu/faculty/Publication\%20Files/12-016 a7e4a5a2-03f9-490d-b0938f951238dba2.pdf (Accessed 11.07.2016).

Luca, M. \& Zervas, G. (2015). Fake It Till You Make It: Reputation, Competition, and Yelp Review Fraud. Harvard Business School, HBS Working Paper Series. Available at http://people.hbs.edu/mluca/fakeittillyoumakeit.pdf (Accessed 11.07.2016).

MAGRAMA (Ministerio de Agricultura, Alimentación y Medio Ambiente; Ministry of Agriculture, Food and Environment). (2011a). Estudio Consumo Alimentario Extradoméstico en España: Hábitos del Consumidor. Madrid: Ministerio de Agricultura, Alimentación y Medio Ambiente. Available at www.magrama.gob.es/es/alimentacion/temas/consumo-y-comercializacion-ydistribucion-alimentaria/OTO\%C3\%910 INVIERNO 2011 tcm7-207355.pdf (Accessed 5-07.2016).

MAGRAMA (Ministerio de Agricultura, Alimentación y Medio Ambiente; Ministry of Agriculture, Food and Environment). (2011b). Tendencias de Consumo Fuera del Hogar. Madrid: Ministerio de Agricultura, Alimentación y Medio Ambiente. Available at www.magrama.gob.es/es/alimentacion/temas/consumoy-comercializacion-y-distribucion-alimentaria/Oto\%C3\%B10 Invierno 2011 21 de julio (2) tcm7-170710.pdf (Accessed 5.07.2016).

MAGRAMA (Ministerio de Agricultura, Alimentación y Medio Ambiente; Ministry of Agriculture, Food and Environment). (2012). Análisis cualitativo de las Tendencias de la Restauración en 2012 en base a la percepción de los operadores del sector. Madrid: Ministerio de Agricultura, Alimentación y Medio Ambiente (Report carried out by El índice $\mathrm{K}$ and MERCASA). Available at www.mapama.gob.es/es/alimentacion/temas/consumo-y-comercializacion-ydistribucion-alimentaria/cualitativo tendencias restauracion 2012 tcm7270844.pdf (Accessed 4.11.2016).

MAGRAMA (Ministerio de Agricultura, Alimentación y Medio Ambiente; Ministry of Agriculture, Food and Environment). (2013). Estudio sobre el mercado extradoméstico de alimentación 2013. Principales variables que caracterizan la demanda extradoméstica de alimentación desde el punto de vista del consumidor. Madrid: Ministerio de Agricultura, Alimentación y Medio Ambiente. (Study carried out by MERCASA, based on information provided by NPDCREST). Available at www.mapama.gob.es/es/alimentacion/temas/consumo-ycomercializacion-y-distribucion-

alimentaria/variables de demanda extradom\%C3\%A9stica 2013 tcm7321941.pdf (Accessed 4.11.2016).

MAGRAMA (Ministerio de Agricultura, Alimentación y Medio Ambiente; Ministry of Agriculture, Food and Environment). (2016). Informe del consumo de 
alimentación en España 2015. Madrid: Ministerio de Agricultura, Alimentación y Medio Ambiente. Available at www.magrama.gob.es/es/alimentacion/temas/consumo-y-comercializacion-ydistribucion-alimentaria/informeconsumoalimentacion2015 tcm7-422694.pdf (Accessed 11.07.2016).

Martín Cerdeño, V.J. (2003). El sector de la restauración en España. Distribución y Consumo, 69, May-June, 5-25.

Martín Cerdeño, V.J. (2004). Alimentación, economía y ocio. Madrid: Ministerio de Agricultura, Pesca y Alimentación.

Martín Cerdeño, V.J. (2009). Alimentación fuera del hogar. Distribución y Consumo, 103, January-February, 5-11.

MMAMRM (Ministerio de Medio Ambiente y Medio Rural y Marino; Ministry of Environment, Agriculture and Fishing. (2008). Estudio de mercado Observatorio del Consumo y la Distribución Alimentaria. Monográfico Restauración. Madrid: Ministerio de Medio Ambiente y Medio Rural y Marino. (Study carried out by Instituto Cerdá). Available at www.mapama.gob.es/es/alimentacion/temas/consumo-y-comercializacion-ydistribucion-alimentaria/hosteleria restauracion 08 tcm7-8062.pdf (Accessed 14.11.2016).

Nelson, P. (1970). Information and Consumer Behavior. Journal of Political Economy, 78 (2), 311-329.

Porter, M. E. (1981). The contributions of Industrial Organization to Strategic Management. Academy of Management Review, 6 (4), 609-620.

PwC (PricewaterhouseCoopers). (2013). Trabajar en 2033. Colección España 2033. Madrid: PwC. Available at www.pwc.es/es/publicaciones/espana2033/assets/trabajar-en-2033.pdf (Accessed 4.07.2016).

Resa, S. (2005). La nueva restauración en España. Distribución y Consumo, 79, January-February, 79-89.

Scherer, F.M. (1980). Industrial market structure and economic performance. Chicago: Rand McNally College Publishing Company (Second edition. First edition: 1971).

Sequeira, A., Roncero, A. \& Martín, V.J. (2003). La franquicia. Madrid: Instituto Nacional del Consumo.

Tauber, E. M. (1972). Why Do people Shop?. Journal of Marketing, 36 (4), October, 46-49. 
Tormo Franquicias Consulting. (2014). Informe de la franquicia 2014. Madrid: Tormo Franquicias Consulting. Available at http://tormofranquicias.es/informacion/informes/ (Accessed 14.11.2016).

Tormo Franquicias Consulting. (2015). Informe Hostelería \& Restauración 2015. Madrid: Tormo Franquicias Consulting. Available at http://tormofranquicias.es/informacion/informes/ (Accessed 4.07.2016).

Tormo Franquicias Consulting. (2016a). Informe de la franquicia 2016. Madrid: Tormo Franquicias Consulting. Available at http://tormofranquicias.es/informacion/informes/ (Accessed 14.11.2016).

Tormo Franquicias Consulting. (2016b). La franquicia: visión 2008-2015. Madrid: Tormo Franquicias Consulting. Available at http://tormofranquicias.es/informacion/informes/ (Accessed 14.11.2016).

Turespaña. (2016). Empleo en Turismo. Primer trimestre 2016. Madrid: Instituto de Turismo de España, Ministerio de Industria, Energía y Turismo (Ministry of Industry, Energy and Tourism). Available at http://estadisticas.tourspain.es/esES/estadisticas/otrasestadisticas/empleoturistico/encuestapoblacion/Notas\%20 de\%20Coyuntura/NotaEmpleoTurismo\%201T2016.pdf (Accessed 4.07.2016).

Urueña, A., Valdecasa, E., Ballestero, M.P., Castro R. \& Cadenas, S. (2015). Estudio sobre Comercio Electrónico B2C 2014. Coordinated by Urueña, A. Madrid: ONTSI (Observatorio Nacional de las Telecomunicaciones y de la Sociedad de la Información; National Observatory for Telecommunications and the Society of Information). Available at www.ontsi.red.es/ontsi/sites/ontsi/files/informe b2c 2014 edicion 2015.pdf (Accessed 15.11.2016).

Warde, A. (1999). Convenience food: space and timing. British Food Journal, 101 (7), 518-527.

Warde, A. \& Martens, L. (2000). Eating Out: Social Differentiation, Consumption and Pleasure. Cambridge: Cambridge University Press.

WIPO (World Intellectual Property Organization). (1973). Admission of observers. Report by the Director General, Fourth Series of Meetings, AB/IV/19, United International Bureaux for the Protection of Intellectual Property, Administrative Bodies of WIPO and of the Unions Administered by WIPO and BIRPI, Geneva, November 19 to 27, 1973. Geneva: WIPO. Available at www.wipo.int/mdocsarchives/AB IV 1973/AB IV 19 E.pdf (Accessed 23.05.2016). 